\title{
EXPERIMENTALISMO E INOVAÇÃO \\ INSTITUCIONAL NAS CONTRATAÇÕES PÚBLICAS DE TECNOLOGIA: o edítal de projetos do Mobilab
}

\author{
重 Felipe Luciano Pires ${ }^{7}$
}

\section{Palavras-Chave \\ "políticas públicas"; "direito administrativo"; "contratações públicas"; "tecnologia"; "inovação"; "licitação".}

\section{SUMÁRIO}

1. Introdução. 1.1. O Direito Administrativo sob a ótica das políticas públicas. 1.2. Os problemas da Lei n 8.666/93 e seus reflexos nas contratações públicas de tecnologia. 1.3. Metodologia. 2. O arranjo institucional do Mobilab. 2.1. A concepção do Mobilab: das manifestações de junho de 2013 ao rearranjo institucional em agosto de 2017. 2.2. A natureza jurídica do Mobilab. 2.3. Desafios envolvendo a estratégia institucional adotada pelo Mobilab. 3. O Edital de Projetos do Mobilab. 3.1. WiFi Livre SP: a origem do modelo de contratação adotado pelo Mobilab. 3.2. A aplicação do modelo do WiFi Livre SP para a realidade do Mobilab. 3.3. A estrutura do Edital de Projetos do Mobilab. 3.4. A realização do concurso público. 3.5. A estrutura dos contratos celebrados entre a Secretaria Municipal de Transportes e as proponentes vencedoras. 3.6. A execução dos contratos. 4. Conclusão: o caso do Mobilab sob a perspectiva do direito nas políticas públicas. 5. Referências.

\section{Resumo}

Passados 25 anos da promulgação da Lei $n^{\circ}$ 8.666/1993, as contratações públicas, principalmente as que tem por objeto insumos

'Possui graduação em Direito pela Universidade de São Paulo (USP) Mestrando em direito e desenvolvimento pela Escola de Direito de São Paulo da Fundação Getúlio Vargas (FGV Direito SP) e advogado. tecnológicos, apresentam um conjunto amplo de obstáculos para sua operacionalização. Dentre eles, é possível citar a baixa discricionariedade conferida a gestores públicos, o distanciamento da doutrina de direito administrativo em relação ao cotidiano da implementação de políticas públicas e a maneira de operacionalizar as ferramentas jurídicas nos processos de desenho dos editais de licitação. Assim, o presente artigo analisa arranjos institucionais que visam a superação dos problemas recorrentes nas contratações públicas de tecnologia. Para isso, a partir de análise documental e entrevistas com atores participantes, apresenta-se um estudo de caso explicativo sobre o Edital de Projetos do Mobilab (Laboratório de Inovação e Mobilidade), licitação feita pela Secretaria Municipal de Transportes de São Paulo. Como resultado, conclui-se que há, nesse caso, experimentalismo e inovação na construção de arranjos para as contratações públicas de tecnologia, tendo em vista que é resultado de um processo de aprendizado institucional que fora iniciado em licitação anterior feita pela Prefeitura de São Paulo, que resultou no programa do WiFi Livre SP. Além disso, demonstra-se que a licitação estudada pode ser um exemplo para os demais setores da Administração Pública, apesar de ainda existirem desafios práticos e uma agenda de pesquisa a ser explorada em relação ao tema das contratações públicas de tecnologia. 


\section{EXPERIMENTATION AND}

INSTITUTIONAL INNOVATION

AT TECHNOLOGIES' PUBLIC

PROCUREMENTS: the Mobilab's

"Edital de Projetos"

\section{Felipe Luciano Pires}

\section{Key-words}

"public policies"; "Administrative

Law"; "public procurement";

"technology"; "innovation"; "bidding".

\section{Abstract}

25 years after the promulgation of the Federal Law n. 8,666/1993, the public procurements present a vast group of issues which disturb their implementation, mainly those whose object is technologies of information. In this sense, three exemplary problems are: (i) the high restraint to public managers' discretion established by the public law legislation in Brazil; (ii) the detachment of the traditional Administrative Law approaches from day-today policies; and (iii) the way of applying legal tools at the design of technologies public procurements' rules. Thus, the present article aims to analyse institutional arrangements that have the intention of overcoming the recurring obstacles at technologies public procurements. In this sense, based on documental analysis and interviews with some of the participants agents, this paper presents a explicative case study regarding the Mobilab's (Innovation and Urban Mobility Laboratory) Edital de Projetos, bidding made by the Municipal Secretary of Transports in São Paulo (SMT). In the end, the research concludes that it can be considered a case that illustrates the experimentalism and innovation at the designing of arrangements for technologies public procurements, considering that it is a result of an institutional learning process which has started at the WiFi LivreSP's bidding, a public policyalso designed by the Prefecture of São Paulo. Besides, the work demonstrates that SMT's policy can also be an example for other Brazilian Public Administration's sectors. However, it is shown that there are still practical challenges and a research agenda that should be explored regarding this subject. 


\section{INTRODUÇÃO}

A Lei $n^{\circ} 8.666 / 1993$ permite que o Estado inove na implementação de arranjos institucionais para a contratação de tecnologia? Através de licitações, o Estado consegue incorporar tecnologias inovadoras a serem aplicadas em políticas públicas? Essas questões foram os elementos orientadores da pesquisa que deu origem ao presente artigo. Para responde-las, realizou-se um estudo de caso sobre o "Edital de Projetos do Mobilab", licitação feita pela Secretaria Municipal de Transportes de São Paulo (SMT), cuja denominação formal é Concurso Público n 001/2015 - SMT.GAB.

Tratou-se de um concurso público cujo objetivo foi a contratação de startups $^{2}$ para o desenvolvimento de Tecnologias da Informação e Comunicação (TIC), a serem aplicadas nas políticas públicas de mobilidade urbana implementadas, principalmente, por duas empresas estatais municipais, a CET (Companhia de Engenharia de Tráfego) ${ }^{3} \mathrm{e} a$ SPTrans (São Paulo Transportes S.A.). ${ }^{4}$ Essa licitação foi coordenada pelo Mobilab (Laboratório de Inovação e Mobilidade), instituição da Administração Pública Municipal criada após as manifestações de junho de 2013.

As duas principais finalidades do Mobilab são a abertura das políticas públicas municipais de mobilidade à participação social e a mudança na relação entre o setor público e empresas que investem em inovação tecnológica na área de mobilidade ${ }^{2}$ Diante da definição estabelecida pelo art. $3^{\circ}$, inciso II do Decreto Mu nicipal de São Paulo $n^{\circ} 55.461 / 2014$, startups são as "pessoas físicas com pretensão de constituir empresa e pessoas jurídicas que possuam processos ou serviços que utilizem software ou serviços de TIC como elementos do seu esforço de inovação, buscando atingir um modelo de negócios repetível, escalável e inserido no mercado".

"Sociedade de economia mista institucionalizada pela Lei Municipa $n^{\circ}$ 8.394/1976. Sua competência abrange o planejamento e operação do tráfego viário na cidade de São Paulo.

"Sociedade de economia mista criada em 1995 e regida pela Lei Mu nicipal $n^{\circ} 13.241 / 2001$, cujas atribuições são o planejamento, gerenciamento e fiscalização do sistema de transporte urbano sobre pneus na cidade de São Paulo. urbana. Por meio desse Laboratório, a SMT buscou estabelecer um local que possibilitasse a interface entre as principais entidades da Administração Pública Municipal no assunto de mobilidade urbana. Ao mesmo tempo, buscou fomentar a integração entre o setor público e startups, seja por meio de maior transparência no fornecimento de dados públicos, ou da internalização de inovações tecnológicas para a aplicação em políticas públicas.

Diante disso, em 2015, ano de publicação do edital da licitação em estudo, o Mobilab possuía dois principais "braços". O primeiro deles era o Programa de Residência de Startups, que consistia na seleção de startups que estivessem desenvolvendo soluções tecnológicas com potencial de trazer impactos positivos à mobilidade urbana de São Paulo para se instalarem durante três meses na sede do Mobilab. Assim, haveria oferta de mentoria às empresas selecionadas, bem como fomento à troca de conhecimento entre os agentes públicos e privados e a criação de um canal de comunicação direto entre as áreas técnicas da Prefeitura e as startups selecionadas.

Já o segundo, o Edital de Projetos de Tecnologia da Informação e Comunicação (TIC), teve a finalidade de contratar, por meio de concurso público, 14 (quatorze) projetos de tecnologia da informação e comunicação inovadores a serem desenvolvidos em conjunto com o Mobilab. Eles seriam aplicados em variados segmentos do setor de transportes, tais como, controle semafórico, fiscalização das concessionárias dos serviços de transporte coletivo de ônibus, monitoramento do trânsito, planejamento de políticas públicas e registro de reclamações de usuários de transporte público. Cada um dos projetos deveria apresentar caráter ino- 
vador e colaborativo desde a concepção das propostas, observadas as diretrizes mínimas estabelecidas pela SMT, de modo a permitir sua aderência aos objetivos do Laboratório e sua integração com os demais projetos e ações em curso.

Dessa forma, a partir de um estudo de caso explicativo ${ }^{5}$ sobre o Mobilab, principalmente acerca do Programa de Edital de Projetos, o artigo objetiva analisar como o arcabouço jurídico das licitações no Brasil, baseado na Lei n 8.666/1993, permite ao setor público a incorporação de tecnologias inovadoras a serem aplicadas em políticas públicas. Em outras palavras, pretende-se observar a maneira pela qual os arranjos institucionais ${ }^{6}$ do Mobilab e do Edital de Projetos foram construídos e funcionaram na prática, de modo a avaliar se apresentaram soluções para os gargalos e problemas das contratações públicas de tecnologia.

Conforme será demonstrado nas próximas subseções do presente artigo, os principais óbices das licitações de tecnologia são: (i) a baixa discricionariedade dos agentes públicos conferida pela legislação nacional; (ii) o distanciamento da doutrina brasileira de Direito Administrativo em relação ao cotidiano das políticas públicas; (iii) a ausência de recursos humanos no interior do Estado que permitam a identificação das tecnologias necessárias para a solução de problemas; e (iv) a influência de agentes econômicos privados no processo de desenho dos editais de licitação.

Com o intuito de examinar como opera a instrumentalização jurídica dessa política pública no interior da "máquina do governo" "Para maiores informações sobre o conceito de estudo de caso explicativo e sua diferença em relação às outras modalidades de estudos de caso, ver item 1.3 ("Metodologia").

كegundo Gomide e Pires (2014, pp. 19 e 20), arranjo institucional pode ser entendido como "o conjunto de regras, mecanismos e processos que definem a forma particular como se coordenam atores e interesses na implementação de uma política pública específica".
(Dallari Bucci, 2013, p. 18), procurou-se verificar se o Edital de Projetos do Mobilab representa uma inovação no uso das ferramentas jurídicas nas contratações públicas de tecnologia. Nesse sentido, analisa-se como ele lidou com os gargalos para a contratação de tecnologia, além de verificar se a solução é capaz de superar os obstáculos. A pesquisa substitui, assim, a comparação entre resultados das políticas públicas e sua previsão legal original por um olhar voltado a compreender o que influencia ações e comportamentos no decorrer do processo jurídico e político de implementação de uma política pública (Annenberg, 2014, p. 17).

A partir desse problema de pesquisa, apresenta-se inicialmente o pano de fundo da pesquisa, que consiste na relação entre as políticas públicas e o direito, e nos problemas apresentados pela Lei $n^{\circ}$ 8.666/1993, que se refletem nas licitações de tecnologia. A segunda parte do artigo apresenta a metodologia aplicada. Em seguida, é apresentado o estudo de caso, sendo que primeiro será descrito o histórico do Mobilab e seu atual arranjo institucional para, em seguida, expor a estrutura do Edital de Projeto. Encerrando o artigo, são feitas considerações finais no campo das contratações públicas de tecnologia a partir do estudo de caso realizado.

1.1. O Direito Administrativo sob a ótica das políticas públicas

A pesquisa no campo das políticas públicas exige essencialmente uma abordagem interdisciplinar, já que a restrição a apenas uma área do conhecimento não é suficiente para sua descrição e compreensão. Em outras palavras, a esfera das políticas públicas é considerada território de múltiplos mode- 
los analíticos (Souza, 2007, p. 69).

Ainda que por muito tempo estudiosos tenham negligenciado a questão, a partir do conceito formulado por Dallari Bucci (2006, p. 39)7, observa-se que o Direito é elemento constitutivo das políticas públicas, visto que há uma variável qualitativa em seu elemento jurídico. Há quatro papeis exercidos pelo Direito em relação às políticas públicas: (i) estabelecer objetivos a serem perseguidos e situar a política no ordenamento jurídico; (ii) conceber condições de participação social, permitindo a vocalização de demandas; (iii) oferecer meios e ferramentas para concretização da política; e (iv) construir arranjos institucionais que sustentam sua efetividade (Coutinho, 2013, p. 194).

Nesse sentido, o direito administrativo pode ser encarado, segundo Coutinho (2013, p. 184), como ferramenta "de disciplina, procedimentalização e de regulação da mobilização de atores mais ou menos organizados na formulação, implementação e avaliação de políticas públicas". Entretanto, essa tarefa não é simples. $O$ direito administrativo brasileiro, por estar baseado tradicionalmente nas ideias liberais de ato administrativo e controle do Estado, não apresenta mecanismos que possibilitem uma visão estratégica e sistêmica das normas jurídicas que embasam os arranjos institucionais de políticas públicas. Esse diagnóstico é evidente quando observada a dificuldade da doutrina jurídica administrativista em lidar com experimentalismo e testes empíricos, dificultando a percepção da realidade dinâmica das po-

\footnotetext{
"Política pública é o programa de ação governamental que resulta de um processo ou conjunto de processos juridicamente regulados - processo eleitoral, processo de planejamento, processo de governo, processo orçamentário, processo legislativo, processo administrativo, processo judicial - visando coordenar os meios à disposição do Estado e as atividades privadas, para a realização de objetivos socialmente relevantes e politicamente determinados. Como tipo ideal, a política pública deve visar a realização de objetivos definidos, expressando a seleção de prioridade, a reserva de meios necessários à sua consecução e o intervalo de tempo em que se espera o atingimento dos resultados".
}

líticas públicas. Consequentemente, isso impede que arranjos institucionais de políticas públicas apresentem os atributos de flexibilidade (a possibilidade do arcabouço jurídico que estrutura o programa de ação governamental servir a mais de uma finalidade) e revisibilidade (característica de a política pública apresentar no seu corpo jurídico mecanismos de ajuste e adaptação) com maior intensidade (Coutinho, 2013, pp. 187 e 197)

Esses fatores são essenciais para o sucesso de determinada ação estatal, visto que a implementação de políticas públicas é uma fase essencialmente imprevisível e que, invariavelmente, demanda a realização de ajustes durante o percurso. Recursos financeiros e operacionais são finitos, as informações nem sempre são completas e a execução está nas mãos de inúmeros atores. Nesse sentido, a fase da implementação transforma a política pública de maneira inexorável, mesmo quando essa não se desvie das trajetórias previstas pelos tomadores de decisões (Marques, 2013, p. 33).

1.2. Os problemas da Lei $n^{\circ} 8.666 / 93$ e seus reflexos nas contratações públicas de tecnologia

Os problemas ressaltados acima (excessiva rigidez das disposições legais e abordagem estática e formal do direito administrativo) são perceptíveis no caso da Lei $n^{\circ}$ 8.666/1993. Apesar de licitações e políticas públicas serem coisas distintas, observa-se que elas estão intrinsecamente ligadas na medida em que muitas vezes a licitação acaba sendo um instrumento para a efetivação da ação estatal configurada sob a forma de política pública. 
Observa-se que a implementação e o desenho de determinadas políticas públicas podem exigir o diálogo com licitações, pois se não for bem estruturada, a etapa de contratação pública pode ser um óbice intransponível. Três exemplos da interface entre licitações e políticas públicas são: (i) contratações públicas sustentáveis ${ }^{8}$; (ii) casos de contratação direta em razão de dispensa ou inexigibilidade de licitação; e (iii) licitações que visam estimular a inovação tecnológica, que é o objeto do presente trabalho.

A partir disso e tendo em vista o período de consolidação democrática, a Constituição Federal de 1988, no seu art. 22, inciso XX$\mathrm{VII}^{9}$, deu centralidade às normas federais na regulação geral das compras públicas que devem ser seguidas por todos os Estados e Municípios, limitando possibilidades de flexibilização dos procedimentos e dos critérios licitatórios adotados (Vojvodic; Astone; Vilella, 2015, p. 16). Além disso, os debates durante a tramitação do projeto da Lei $n^{\circ}$ 8.666/1993 no Congresso Nacional abordaram principalmente o combate à corrupção, muito em razão do caso PC Farias, que acarretou na renúncia e no posterior impeachment do então Presidente da República, Fernando Collor. Nesse sentido, acreditava-se que a prevenção à prática de atos lesivos à moralidade e impessoalidade pública deveria passar, necessariamente, pela diminuição da discricionariedade dos gestores públicos (Rosilho, 2013, pp. 20 e 95).

Diante disso, os legisladores de 1993, em continuidade a um movimento iniciado

\footnotetext{
'De acordo com Palma (2015, p. 81), "contratações públicas sustentá veis são caracterizadas pela observância de critérios de sustentabili dade na fase da licitação (licitações sustentáveis) ou no momento da celebração do contrato (contrato administrativo sustentável)." (grifos da autora citada)

${ }^{9}$ Art. 22. Compete privativamente à União legislar sobre: (...) XXVII normas gerais de licitação e contratação, em todas as modalidades, para as administrações públicas diretas, autárquicas e fundacionais da União, Estados, Distrito Federal e Municípios, obedecido o disposto no art. 37, XXI, e para as empresas públicas e sociedades de economia mista, nos termos do art. $173, \S 1^{\circ}$, III.
}

pelo Decreto-Lei $\mathrm{n}^{\circ} 2.300 / 1986$, optaram pela descrição detalhada dos processos de contratação pública, antes definidos pelas instâncias inferiores da Administração, havendo uma "superlegalização" das normas gerais de licitações. Em outras palavras, prevaleceu a ideia de que as boas contratações públicas seriam aquelas resultantes do cumprimento estrito de regras procedimentais minuciosas e rígidas, aplicáveis a todos os entes federativos (Rosilho, 2013, pp. 91 e 226).

Além disso, o modelo adotado pela Lei $n^{\circ}$ 8.666/1993 tende a perpetuar equívocos na montagem dos arranjos institucionais, visto que sua correção depende da promulgação de lei, exigindo mobilização dos Poderes Legislativo e Executivo. A transferência de praticamente toda a competência decisória do administrador para o legislador também acarreta o bloqueio à inovação e à criatividade na gestão pública, pois incentiva que os agentes, diante do receio da declaração de ilegalidade de seus atos, se limitem a reproduzir comportamentos expressamente descritos no texto legal (Rosilho, 2013, p. 230). Um exemplo disso é o art. 40 da referida Lei, que por meio de 17 (dezessete) incisos determina minuciosamente qual deverá ser a estrutura dos editais de licitação.

Esses gargalos afetam, entre outras, as contratações públicas de tecnologia. Em geral, gestores públicos focam excessivamente no procedimento licitatório e pouco no resultado. A licitação é encarada como um check-list de requisitos que devem ser cumpridos, sem a visão do resultado a que esses processos se voltam. Nesse sentido, o formalismo adotado pelos órgãos de controle e a inflexibilidade da legislação tornam o processo de contratação de tecnologia pouco propenso a inovações e faz com que gestores pequem 
por excesso nos editais, a partir da descrição minuciosa do equipamento ou serviço pretendido, bem como os procedimentos a serem adotados pelos contratados, dificultando soluções inovadoras (Vojvodic; Astone; Vilella, 2015, p. 35).

Observa-se ainda um outro problema: a falta de capacidade institucional para a Administração Pública identificar ou reconhecer a demanda por tecnologia, bem como desenhar editais de licitações que possibilitem selecionar a melhor solução para a sua demanda (Vojvodic; Astone; Vilella, 2015, p. 34). Para isso, seria necessária a realização de análises críticas dos resultados de custo-benefício das contratações públicas de tecnologia, o que muitas vezes não é feito pelos gestores ${ }^{10}$, que acabam por julgar apenas com base no menor preço, critério de escoIha que seria adequado somente para aquisição de produtos uniformes, cujas especificações técnicas não sejam muito variáveis, o que em regra não é o caso de produtos de tecnologia.

Compras públicas dessa natureza são caracteristicamente peculiares, não podendo ser aplicados modelos institucionais formulados para licitações de natureza completamente distinta. Apesar da existência do Decreto Federal $n^{\circ} 7.174 / 2010$, que regulamenta a contratação de bens e serviços de informática pela Administração Pública Federal, tal questão não foi solucionada ainda. Isso porque o referido ato normativo pautou-se, principalmente, por especificar regras que já estavam presentes na Lei $n^{\circ}$ 8.666/1993 e diminuir a discricionariedade do administrador público por meio da definição dos procedimentos a serem adotados. Um exemplo disso é a previsão no art. $9^{\circ}$ do

referido Decreto que estabelece que as contratações de tecnologia deverão adotar os tipos de licitação "menor preço" ou "técnica e preço".

Destaque-se que o Novo Marco Legal da Inovação Tecnológica (Lei Federal $n^{\circ}$ 13.243/2016) procura lidar parcialmente com essas questões ao incluir, no art. $1^{\circ}$, inciso XII, e no art. 27, inciso $\vee$ da Lei de Inovação (Lei Federal $n^{\circ}$ 10.973/2004), que a promoção do controle por resultados na avaliação de atividade inovadoras é um dos princípios jurídicos a serem observados por gestores públicos e controladores. Caso seguida, essa nova legislação teria o potencial de modificar o processo de implementação e avaliação de políticas públicas (Coutinho; Mouallem, 2016, p. 211).

Os gestores públicos entrevistados na presente pesquisa também apontaram que há uma grande influência das grandes empresas de tecnologia, que em geral já possuem outros contratos celebrados com o Poder Público, na condução dos processos de desenho das licitações de contratação dessa natureza feitas pela Prefeitura e pelo Governo Estadual de São Paulo, bem como pela União"n.

Essa atuação, de acordo com as entrevistas feitas, poderia ser realizada através da influência nos processos da fase interna da licitação. Ao invés de imporem seus produtos explicitamente, por exemplo, as empresas atuariam levando o Poder Público a elaborar editais que se encaixem dentro de suas limitações técnicas, mesmo sem motivos claros. Em outras palavras, elas atuariam no sentido de fazer com que a única conclusão possível da Administração Pública fosse a de que somente os seus bens ou serviços fornecidos atendam à demanda do órgão

Idem nota de rodapé 10. 
licitante ${ }^{12}$.

A influência de empresas de tecnologia da informação nas contratações públicas pode adotar outras formas de atuação para contornar a realização da licitação. Um exemplo é a aquisição, por empresas estatais, de participação acionária em empresas privadas, possibilitando sua contratação com dispensa de licitação ${ }^{13}$. Da mesma forma, há casos em que a dispensa é implementada através da celebração de contratos de parceria, com objetivo exclusivo de prestar serviços à Administração ${ }^{14}$.

Diversos mecanismos fariam com que as descrições editalícias fossem desenhadas de forma a garantir demanda para produtos que já foram desenvolvidos, mas ainda não estão no mercado. Observa-se, assim, que haveria uma prevalência de interesses econômicos privados, em detrimento da busca pela solução mais eficiente ao Poder Público em termos tecnológicos e financeiros ${ }^{15}$.

Ademais, grandes empresas da área também inviabilizam a participação de outros concorrentes nas licitações através da impetração de recursos administrativos durante e após o julgamento das propostas da licitação. Isso faz com que pequenas e médias empresas acabem desistindo de participar do certame, por não possuem tempo e recursos financeiros suficientes para encarar disputas jurídicas e administrativas que podem durar meses ou anos até serem solucionadas ${ }^{16}$.

Em suma, as consequências dos problemas citados acima podem ser resumidas, 12 dem nota de rodapé 10

i3Para maiores detalhes, ver TCU, Acordão n 1220/2016. Plenário. Relator: Min. Bruno Dantas. Sessão: 18/05/2016. Disponível em: http://bit. y/2fiH9St. Acesso em 19/09/2017.

${ }^{14}$ O ESTADO DE S. PAULO. Caixa deve cancelar aquisição da Capgemini, diz TCU. 20/05/2016. Disponível em: http://economia.estadao.com $\mathrm{br} /$ noticias/geral,caixa-deve-cancelar-aquisicao-da-capgemini--diz-tcu,10000052427. Acesso em: 19/09/2017.

15 dem nota de rodapé 10.

Idem nota de rodapé 10 conforme constatou o Tribunal de Contas da União (2012, pp. 44 e 45), em: (i) contratar produtos e serviços que não agreguem efetivamente valor ao órgão e não ajudem a alcançar os objetivos definidos nos planos; (ii) contratar soluções de Tecnologia da Informação e Comunicação (TIC) com preços acima dos valores do mercado; (iii) contratar soluções de TIC que ultrapassem a necessidade do órgão; (iv) efetuar recebimentos provisórios e definitivos sem embasamento, isto é, os responsáveis não terem certeza de que o órgão está recebendo pelo que paga; e $(v)$ efetuar pagamento com valor não correspondente ao produto/serviço recebido.

\subsection{Metodologia}

Para apresentar o modo como as ferramentas jurídicas foram utilizadas para a solução de gargalos da contratação pública de tecnologia para mobilidade urbana, optou-se pela metodologia do estudo de caso explicativo, que, segundo Yin (2015, p. 244), trata-se de "um estudo de caso cujo propósito é explicar como ou por que uma condição ocorreu (por exemplo, como ou por que uma sequência de eventos ocorreu ou não)"17. Esse método foi utilizado em razão dos objetivos da presente pesquisa, que pretende investigar os motivos que embasaram as decisões feitas pelos gestores públicos responsáveis pela construção jurídica do Mobilab e do Edital de Projetos, além de descrever a operacionalização dessa licitação e dos contratos administrativos celebrados. Junto a isso, ${ }^{17}$ Além do estudo de caso explicativo, Yin (2015, p. 244) apresenta outras duas modalidades de estudo de caso: (i) estudo de caso descritivo, cujo objetivo é descrever um fenômeno em seu contexto real; e (ii) estudo de caso exploratório, em que se objetiva identificar questões ou procedimentos de pesquisa a serem utilizados em um estudo subsequente. Diante disso, observa-se que o estudo de caso explicativo se diferencia do descritivo na medida em que ele vai além de apresentar o caso no seu contexto e procura investigar os motivos pelos quais o caso estudado ocorreu de determinada maneira. De outro lado, o estudo de caso explicativo é diferente do exploratório, pois, em regra, este é estruturado sem a realização de hipóteses de pesquisa ou perguntas que demandam como ou por que houve a ocorrência de determinado evento. 
empregou-se a combinação de técnicas de análise de conteúdo de documentos e entrevistas com atores centrais da política pública analisada.

Além da legislação sobre contratações públicas, mobilidade urbana e tecnologia, os documentos selecionados para análise foram o Edital do Concurso Público n 001/2015 - SMT.GAB e seus respectivos anexos ${ }^{18}$, bem como os contratos celebrados entre os vencedores de cada um dos projetos do Mobilab e o Poder Público ${ }^{19}$. Além disso, em 07/06/2017 e 29/11/2017, com o intuito obter o andamento do processo licitatório, buscou-se por publicações no site Diário Oficial da Cidade de São Paulo ${ }^{20}$ que tratassem do Mobilab e principalmente do Concurso de Projetos $^{21}$.

Em um segundo pilar da metodologia do trabalho, em maio e junho de 2017, foram feitas entrevistas semiestruturadas com os atores relevantes na institucionalização do Mobilab e no processo de formulação, contratação e execução dos projetos de tecnologia. Ao utilizar esse método, pretendeu-se captar os pontos críticos dos projetos e das referidas licitações, buscando entender a dinâmica de funcionamento do arranjo institucional. Sem a devida contextualização feita pelas entrevistas, não seria possível identificar os motivos das escolhas das ferramentas jurídicas, a maneira como foi construída a política pública, nem conhecer os problemas encontrados durante a execução.

Assim, a partir de seleção prévia, foram entrevistados cinco atores, sendo dois gestores públicos da Prefeitura de São Paulo e repre${ }^{18} \mathrm{~A}$ íntegra do Edital está disponível em http://mobilab.prefeitura.sp. gov.br/projetos/. Acesso em 27/04/2017.

${ }^{19}$ Todos os contratos celebrados estão disponíveis em http://transparencia.prefeitura.sp.gov.br/contas/Paginas/Contratos-v2.aspx. Acesso em 27/04/2017.

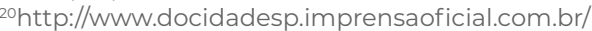

${ }^{21} \mathrm{Em}$ ambas as datas, foram utilizadas as seguintes chaves de busca: "Mobilab"; "Concurso Público n 001/2015"; "Concurso Público n $01 / 2015 "$ sentantes de três dentre as quatro empresas contratadas até 07/06/201722, data em que foi realizado o referido levantamento no Diário Oficial da Cidade. Tendo em vista que há dois grupos distintos, optou-se pela formulação de dois roteiros de entrevista, um que foi aplicado para o diálogo com atores públicos e outro utilizado com atores privados.

Além disso, com o intuito de obter maiores detalhes e quantidade de informações úteis para a pesquisa, foi feita a opção de não divulgar os nomes dos entrevistados. Caso contrário, a publicidade poderia constranger os interlocutores e deixá-los menos à vontade para se aprofundarem em pontos delicados. A confidencialidade foi garantida por meio de termo de consentimento, que também trata da autorização da gravação do áudio das entrevistas e a utilização dos dados colhidos em textos acadêmicos. Ao longo do texto, as referências aos trechos das entrevistas serão feitas de maneira genérica ou por meio das seguintes denominações: gestor público I e II e contratadas A, $\mathrm{B}$ e $\mathrm{C}$.

\section{O ARRANJO INSTITUCIONAL DO MOBILAB}

Passadas as apresentações do problema de pesquisa e da metodologia adotada, a presente seção está dividida em três principais partes. Inicialmente, serão descritos o contexto político e social em que o Mobilab iniciou suas atividades, bem como as premissas que o originaram. Nessa mesma parte, será descrito o arranjo institucional do Laboratório, segundo a Portaria $n^{\circ}$ 76/2015-SMT. GAB (Portaria $\left.n^{\circ} 76\right)$ e a Portaria Intersecretarial $n^{\circ}$ 1/2017-SMIT/SMT (Portaria Intersecretarial). Posteriormente, haverá a tentati${ }^{22}$ Não foi possivel entrar em contato com uma das empresas através dos meios empregados para comunicação com os demais entrevistados, quais sejam e-mail, mensagens de texto pelo celular e ligações telefônicas. Desse modo, as entrevistas foram realizadas com as outras três contratadas. 
va de definir a natureza jurídica do Mobilab. Por fim, serão apontados alguns gargalos decorrentes da estrutura institucional apresentada na primeira parte.

\subsection{A concepção do Mobilab: das manifesta-} ções de junho de 2013 ao rearranjo institucional em agosto de 2017

As manifestações de junho de 2013, a despeito de terem sido um movimento difuso tanto nas reivindicações quanto nas ideologias políticas dos participantes, foram caracterizadas pelo denominador comum da redução da tarifa do transporte público. Elas trouxeram a mobilidade urbana para o centro das discussões sobre políticas públicas. O tema extrapolou o espaço dos movimentos sociais setoriais, como o Movimento Passe Livre (MPL), e passou a ser discutido amplamente pela sociedade, sendo objeto de estudos acadêmicos, projetos de atos normativos no Poder Legislativo e de políticas no Poder Executivo (Gomide; Galindo, 2013, p. 27).

Uma das estratégias da Prefeitura de São Paulo para responder às reivindicações foi a implementação da agenda de transparência ativa ${ }^{23}$ no setor de transportes, baseada principalmente na divulgação de Dados Governamentais Abertos (DGA) ${ }^{24}$, cujo potencial de impulsionar inovações e aperfeiçoamento de políticas públicas ainda era pouco explorado, além de sua utilização encontrar resistências em alguns órgãos da Administração Pública Municipal. Assim, em setem-

\footnotetext{
23Transparência ativa é a divulgação de dados por iniciativa do próprio setor público, ou seja, quando são tornadas públicas informações, in dependente de requerimento, utilizando principalmente a Internet. Já a transparência passiva é a disponibilização de informações públicas em atendimento a demandas específicas de uma pessoa física ou jurídica. Fonte: http://www.acessoainformacao.gov.br/perguntas-frequentes/aspectos-gerais-da-lei\#9. Acesso em 24/07/2017.

${ }^{24}$ Segundo Vaz, Ribeiro e Matheus (2010, p. 46), DGA "são bases de dados em estado bruto, para serem livremente manipuladas, filtradas ou cruzadas com outras, inclusive permitindo a construção de novas aplicações e conhecimentos pela própria sociedade civil".
}

bro de 2013, realizou-se a API (Application Programming Interface) dos GPS dos ônibus municipais. Em outras palavras, foram abertos os dados sobre a localização em tempo real de todos os automóveis utilizados para a prestação do serviço de transporte público coletivo sobre pneus na cidade ${ }^{25}$.

No mês seguinte, foi feita uma hackatona ${ }^{26}$ com os referidos DGA, o que resultou em dois principais resultados: (i) a identificação de falhas no banco de dados disponibilizado; e (ii) a produção de softwares. Três meses após a hackatona, cerca de 180 (cento e oitenta) pessoas estavam utilizando os dados abertos dos GPS dos ônibus e 60 (sessenta) apps foram desenvolvidos, tais como os que permitem identificar a localização dos ônibus de determinada linha em tempo real27 28.

Posteriormente, em março de 2014, a SMT, em conjunto com a SPTrans e a CET, deu início às atividades do Mobilab ${ }^{29} \mathrm{com}$ a realização de uma nova hackatona, cujo objeto era os DGA do trânsito da cidade, disponibilizados pela CET. A criação do Laboratório visou introduzir inovações no setor público e mudar o relacionamento da administração ${ }^{25}$ Informações presentes na palestra concedida por Ciro Biderman na Faculdade de Direito da Universidade de São Paulo em 15/09/2015. Disponível em: https://www.youtube.com/watch?v=J8cvbq3vqoM\&$\mathrm{t}=4248 \mathrm{~s}$. Acesso em 13/07/2017.

${ }^{26}$ Segundo 0 art. $5^{\circ}$, inciso I do Decreto Municipal de São Paulo $n^{\circ}$ $55.461 / 2015$, hackatonas são "eventos realizados pela Administração, sob responsabilidade das Secretarias Municipais ligadas aos respectivos, reunindo agentes públicos empreendedores, programadores, designers e outros interessados, com o objetivo de buscar soluções tecnológicas para resolver problemas urbanos como mobilidade, saúde, educação e outras, mediante acesso à base de dados públicos, nos termos da lei".

${ }^{27}$ Idem nota de rodapé 25 .

${ }^{28} \mathrm{Apesar}$ de não ser o objetivo central do presente trabalho, vale ressaltar que a interação entre licitações e dados abertos se apresenta como uma agenda de pesquisa a ser explorada. Ao assumirem formato semelhante a um concurso público, as hackatonas apresentam-se como uma via alternativa às contratações públicas, tornando-se uma espécie de institutional bypass (Prado, 2011, p. 19). Isso porque não estão sujeitas a regulamentação da Lei nº $8.666 / 1993$ e possibilitam o desenvolvimento de softwares que, caso desenvolvidos através de licitações, demandariam uma quantidade substancial de tempo e recursos públicos. Além disso, ao não ser necessário o apontamento prévio do formato nem dos meios a serem empregados, elas possibilitam que os participantes levem aos Poder Público soluções tecnológicas criativas e inventivas.

${ }^{29}$ Vale ressaltar que a relação entre esses eventos também e a criação do Laboratório também é visível diante da constatação de que o espaço físico do Mobilab atualmente é o local onde foi realizada a hackatona dos GPS dos ônibus. 
pública com tecnologia. A intenção de inovar fica evidente quando o gestor público I, quando questionado sobre os motivos para a criação do Mobilab, afirmou que sempre discordou da maneira como se fazia inovação no setor público. O entrevistado externou que um dos seus objetivos, desde sua entrada nos quadros da Prefeitura de São Paulo, era alterar o setor de tecnologia da informação na área de transportes.

Pretendeu-se construir inovações institucionais nas contratações públicas e, ao mesmo tempo, evitar a manutenção do modelo passivo de consumo de tecnologia, em que produtos são desenvolvidos previamente, em código fechado, com licenças proprietárias e com um custo sistemático para o erário público ${ }^{30}$. Desde o começo da sua implementação, o Mobilab está atrelado a outras duas políticas públicas da Prefeitura de São Paulo, o Tech Sampa e o São Paulo Aberta. ${ }^{31}$

Apesar disso, a institucionalização do Laboratório e a construção formal do seu arranjo institucional viria a ocorrer somente em outubro de 2015, ou seja, 19 (dezenove) meses após o início das suas atividades com a publicação da Portaria $n^{\circ} 76$. Segundo o gestor público II, isso ocorreu em razão de escolha de prioridades em primeiro colocar em prática as políticas públicas de maneira desburocratizada, para depois pensar em institucionalizar o Laboratório.

Sendo assim, o Mobilab foi definido como iniciativa de construção, difusão e compartilhamento de conhecimento e dados em mobilidade na cidade de São Paulo (art. $1^{\circ}$, 30Tais informações estão disponiveis no portal eletrônico do Mobilab: http://mobilab.prefeitura.sp.gov.br/sobre/. Acesso em 13/07/2017. ${ }^{31}$ O Tech Sampa, instituído pelo Decreto Municipal n 55.461/2014, visa estimular a cultura de inovação e empreendedorismo tecnológico, promover o desenvolvimento do setor de TIC, bem como desenvolver e consolidar o ecossistema de startups na cidade, conectando-o aos demais polos mundiais de tecnologia. Já o São Paulo Aberta tem objetivo de aumentar a transparência e acesso às informações públicas, aprimorar a participação social, fomentar a inovação tecnológica, fortalecer a integridade pública, melhorar a governança pública e aperfeiçoar a prestação de serviços públicos. caput). Seus cinco principais objetivos são: (i) integração física e tecnológica da mobilidade urbana; (ii) inovação tecnológica para melhoria da mobilidade urbana; (iii) abertura de dados sobre o sistema de transporte na cidade; (iv) análise empírica da efetividade de políticas municipais em mobilidade; e (v) trabalho em conjunto com empresas privadas da área de tecnologia para promoção de alternativas inovadoras aos desafios da mobilidade urbana (art. $1^{\circ}$, incisos I a V).

Para o pleno funcionamento do Mobilab e a coordenação interna de suas atividades, a Portaria em questão criou a Coordenação Institucional do Laboratório (Cl-Mobilab). Principal instância decisória dentro da governança estabelecida pela Portaria $n^{\circ} 76$, ela era composta por três titulares, cada um deles indicados pelo Secretário Municipal de Transportes, pelo Chefe de Gabinete da SPTrans e pelo Chefe de Gabinete da CET. (art. $2^{\circ}$, caput e art. $3^{\circ}$ ). O Laboratório não tem fundos e orçamento próprio, sua atuação se dá com base nos ativos e recursos, humanos e financeiros, das entidades que o integram (SMT, SP Trans e CET). Essas entidades são responsáveis pela contratação de bens e serviços para a realização das atividades do Mobilab (art. $6^{\circ}$ ).

No entanto, em agosto de 2017, a SMT e a Secretaria Municipal de Inovação Tecnológica (SMIT) publicaram a Portaria Intersecretarial com o intuito estabelecer cooperação técnico-administrativa para reestruturação da governança do Mobilab (art. $1^{\circ}$, caput) ${ }^{32}$. Assim, a SMT tem por competência realizar a gestão e o acompanhamento técnico dos projetos do Mobilab, enquanto que a SMIT tem por atribuição facilitar o acesso aos equipamentos e insumos tecnológicos necessários ao funcionamento do Laboratório (arts. $6^{\circ}$ e $7^{\circ}$ ).

${ }^{32}$ As entrevistas para a presente pesquisa não abordaram essa Por taria, pois foram realizadas antes de sua edição. Por isso, todas as falas dos entrevistados mencionadas no artigo foram formuladas com base no arranjo institucional da Portaria $n^{\circ} 76$. 
As duas principais mudanças foram o nome do Laboratório e as instâncias de coordenação. A denominação do Mobilab passou de "Laboratório de Mobilidade Urbana e Protocolos Abertos" para "Laboratório de Inovação e Mobilidade" (art. $1^{\circ}, \S 1^{\circ}$ ) e instituiu-se o modelo de "Governança Compartilhada", composto por duas instâncias: Comitê Gestor (CG-Mobilab) ${ }^{33}$ e Comitê Operacional ${ }^{33} \mathrm{O}$ CG-Mobilab é a instância máxima do modelo de governança do Laboratório. Tem como objetivos decidir sobre os Planos de Trabalho, promover a integração das equipes estatais e determinar a alocação dos recursos disponíveis (art. $4^{\circ}$, caput). Deve promover projetos que façam uso de software livre, de manutenção de códigos abertos, do fomento à participação social, da abertura de dados à população
(CO-Mobilab) (art. $\left.3^{\circ}\right)^{34}$. Com o intuito de facilitar a visualização do arranjo apresentado, os organogramas abaixo mostram a estrutura do Mobilab antes e depois da edição da Portaria Intersecretarial.

\footnotetext{
de contratação preferencial a empresas nascentes ou de até médio porte (art. $5^{\circ}$, parágrafo único). Seus membros são Secretário Municipal de Inovação e Tecnologia, o Secretário Municipal de Mobilidade e Transporte e no Coordenador do CO-Mobilab.

${ }^{34} \mathrm{O}$ CO-Mobilab é responsável por atos essenciais ao funcionamento do Laboratório, principalmente pela elaboração de Planos de TrabaIho anuais que fixarão atividades a serem realizadas pelo Mobilab, conforme art. 15 da Portaria Intersecretarial. É composto por um coordenador indicado pelo Secretário Municipal de Mobilidade e Transportes e três membros indicados pelo CG-Mobilab, escolhidos dentre servidores da SMT, empregados da SPTrans ou CET.
}

\section{Figura 1 - Organogramas institucionais do Mobilab antes depois da edição da Portaria Intersecretarial}

\section{Antes}



\section{Depois}

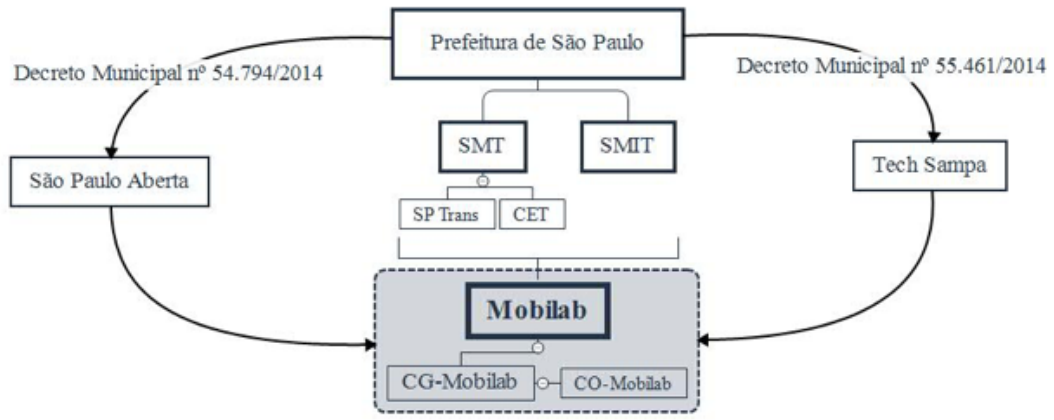

\subsection{A natureza jurídica do Mobilab}

A partir do arranjo institucional apresentado acima e conforme as categorias tradicionais de direito administrativo, observa-se que o Mobilab poderia ser classificado como um órgão público pertencente à Administração Pública Direta. Isso porque foi criado pela SMT e não é dotado de personalidade jurídica, já que o art. 16 da Portaria Intersecretarial estabelece que as contratações de serviços e parceiros para as atividades do Laboratório serão feitas em nome das entidades que o integram. Essa característica é essencial para excluir a possibilidade de enquadrar o Laboratório como ente da Administração Pública Indireta, segundo o art. $4^{\circ}$, inciso II do Decreto-Lei n²00/1967.

Por outro lado, vale ressaltar que a estrutura estabelecida pela referida Portaria não se enquadra no modelo tradicional de um órgão público. Nota-se que o Laboratório pode ser encarado como uma instituição de integração entre as esferas da Administração Pública Municipal Direta e Indireta, visando a implementação de políticas públicas de transportes que lancem mão de inovação 
tecnológica e Dados Governamentais Abertos. Essa característica institucional e jurídica do Mobilab não estar vinculado somente um órgão público ou entidade da Administração Pública Municipal, pode ser visto como um dos fatores de sucesso de suas atividades, conforme será visto nas seções seguintes.

Isso fica evidente ao observar que por não ficar "embaixo de ninguém" e ser "uma caixinha meio solta", conforme descrito pelo gestor público I, evitou-se que a oposição e a pressão de setores internos da Prefeitura de São Paulo resultassem no insucesso de seus programas. Caso a roupagem jurídica do Mobilab fosse diversa, poderiam ter ocorridos problemas em relação à implementação do concurso público de tecnologia, como ocorreu no caso do LabProdam, descrito no próximo capítulo.

2.3. Desafios envolvendo a estratégia institucional adotada pelo Mobilab

Diante do que foi exposto anteriormente, observa-se que a estratégia institucional ${ }^{35}$ dos atores integrantes do Mobilab foi primeiramente colocar em prática os programas pouco burocráticos, consolidando a agenda de dados abertos e inovação no setor de transportes da cidade, para depois se dedicar à institucionalização do Laboratório. Apesar do sucesso de tal opção, visto que o Mobilab continua em atividade atualmente, o gestor público II suscitou dois tipos de desafios e problemas que já surgiram e um que poderá surgir em razão dessa opção.

Em primeiro lugar, devido ao fato de depender dos recursos financeiro e humanos das entidades que o integram, o Mobilab se deparou com situações de perder o servidor público responsável pela parte de informáti-

\footnotetext{
${ }^{35}$ Por estratégia institucional, me refiro tanto ao momento em que se optou pela institucionalização do Mobilab, quanto ao arranjo institucional estabelecido pela Portaria $n^{\circ} 76$ e pela Portaria Intersecretarial.
}

ca, pois ele foi realocado para a CET. Segundo o entrevistado, tal situação se tornou ainda mais grave diante do enxuto quadro funcional disponível ${ }^{36}$ e ela não teria ocorrido caso o Mobilab fosse "mais institucionalizado".

Essa dependência em relação às entidades integrantes também se reflete negativamente na indisponibilidade de bens utilizados cotidianamente por entes da Administração Pública. O gestor II também disse que para conseguir café e impressora, por exemplo, o Laboratório depende da doação ou empréstimo de entidades da Administração Pública Municipal, por não ser um "centro de custos". Em outras palavras, a Lei Orçamentária Anual do Município de São Paulo não prevê essa instituição na destinação de recursos públicos para a manutenção de suas atividades.

O terceiro problema citado refere-se à possibilidade de o Mobilab ser extinto facilmente, caso seja a vontade da gestão em mandato na Prefeitura. Trata-se de consequência da institucionalização realizada exclusivamente via Portaria secretarial, sem a utilização de outros instrumentos jurídicos para a construção de um "colchão de proteção" à instituição, que evitaria sua extinção através da revogação desse ato normativo por decisão unilateral do Secretário Municipal de Transportes 3738 .

\footnotetext{
36 De acordo com o gestor público II, em junho de 2017, o Mobilab contava com quatro agentes públicos para suas atividades do cotidiano: (i) uma secretária-executiva, que auxilia o Coordenador do Mobilab; (ii) um técnico de informática, responsável pela programação e configuração dos servidores; (iii) um agente público com experiência em mobilidade urbana, que auxilia os projetos nas partes técnica e estatística de mobilidade urbana; e (iv) um responsável pela intermediação da relação entre startups e Prefeitura de São Paulo, bem como pela atualização das páginas do Mobilab em redes sociais.

Entretanto, essa questão não foi vivenciada na prática até junho de 2017, pois o Mobilab foi desenvolvido na gestão do então Prefeito Fernando Haddad e a gestão do Prefeito João Dória Jr. avaliou positivamente a política pública em estudo, dando o suporte necessário para a continuidade das atividades do Mobilab.

${ }^{38}$ Vale ressalvar que a institucionalização por meio de ato normativo "mais robusto" que a Portaria secretarial, tal como a lei ordinária, não necessariamente garante o êxito de uma instituição. Um exemplo disso é o caso das agências reguladoras, que apresentam problemas em relação à vacância nos de cargos de diretoria e à falta de publicidade nas deliberações. Para maiores detalhes, ver Salama e Barrionuevo (2016)
} 


\section{O EDITAL DE PROJETOS DO MOBILAB}

Tendo em vista o arranjo institucional apresentado acima, essa seção objetiva detalhar os processos de formulação e implementação do Concurso Público do Laboratório, além de apresentar as estruturas jurídicas que compõem essa licitação. A abordagem foi dividida em três principais eixos. Inicialmente, serão descritas as premissas que embasaram o Edital de Projetos, que pode ser visto como um desdobramento do modelo de contratação pública aplicado na política do WiFi Livre SP. Em seguida, será apresentada a estrutura das regras do Edital do Concurso para a seleção das proponentes vencedoras e como isso ocorreu na prática. Por fim, a mesma lente de análise será aplicada para o contrato celebrado entre a SMT e as empresas vencedoras.

3.1. WiFi Livre SP: a origem do modelo de contratação adotado pelo Mobilab

A despeito de o Edital de Projetos do Mobilab ser uma experiência inovadora nas contratações públicas de tecnologia, sua origem está atrelada ao Programa WiFi Livre SP. Essa política pública da Prefeitura de São Paulo, implementada a partir de 2013 e institucionalizada pela Lei Municipal $n^{\circ}$ 16.685/2017, visa disponibilizar sinal de WiFi gratuito nas principais localidades de cada um dos distritos da cidade.

Na prestação desse serviço, o Poder Público define os espaços públicos onde a tecnologia será instalada e a fiscalização, pagamento e monitoramento das disposições contratuais. As empresas contratadas ficam a cargo da infraestrutura entre o usuário final (cidadão conectado à rede) e a internet, além da disponibilização de informações estratégicas e sistemas de forma a facilitar o acompanhamento da qualidade do serviço prestado. Essa função de monitoramento também é realizada por uma terceira parte, o Simet Box, que simula a experiência do usuário em tempo real e gera relatórios sequenciais sobre a qualidade dos serviços de internet em cada um dos locais em que o programa é operacionalizado (Astone, 2015, p. 7).

Tal arranjo foi estabelecido pelas regras contidas no Edital do Pregão Eletrônico $n^{\circ}$ 08.006/1339, realizado pela Prodam (Empresa de Tecnologia da Informação e Comunicação do Município de São Paulo). Durante a sua elaboração, tendo em vista os problemas das licitações de tecnologias que foram descritos na introdução do trabalho (abordagem estática e formal do direito administrativo, baixa discricionariedade conferida aos gestores públicos e modo de operação dos instrumentos jurídicos durante elaboração dos editais), os agentes públicos participantes desse projeto identificaram as brechas nas fases dos processos licitatórios que permitiam a captura do Poder Público por empresas privadas de tecnologia, conforme dito pelo gestor público I. Diante disso e com base em análises de custo-benefício jurídico ${ }^{40}$, optaram por deixar de lado o modelo contratual convencional, em que o Poder Público visa contratar pelo menor preço possível a partir de descrição minuciosa do objeto da licitação, e realizaram uma complexa descrição de todas as variáveis que importam para a execução e a entrega do objeto contratual (Astone, 2015, p. 2).

Nesse sentido, aplicou-se o modelo de contratação baseado na definição dos resulta-

39 O Edital do Pregão Eletrônico está disponível em http:/le-negocioscidadesp.prefeitura.sp.gov.br/DownloadEdital.aspx?!=A6rub\%2FZydmY\%3D\&e=vWO2TOaf5n4\%3D. Acesso em 03/08/2017.

${ }^{40}$ De acordo com o gestor público I, a análise de custo-benefício refere-se ao exame do quanto de recursos públicos será dispendido versus a qualidade do produto final, principalmente, no "leque de opções" da Lei Federal n 8.666/1993. 
dos esperados. Em outras palavras, tendo em vista que a Prefeitura de São Paulo é uma consumidora de um serviço e/ou de um equipamento de tecnologia, ela apenas precisa estabelecer o que deseja receber do fornecedor e como isso seria medido. Assim, as concorrentes da referida licitação competem entre si para entregar o objeto licitado, tendo liberdade para definir os meios pelos quais isso será feito (Astone, 2015, p. 2).

Esse modelo fez com que houvesse uma mudança no foco da elaboração das propostas apresentadas, que passou a abarcar também a inovação e a adaptabilidade dos projetos. Por outro lado, o valor das propostas teve papel central no julgamento do certame, visto que, por se tratar de modalidade licitatória de Pregão, o item 7.1. do Edital ${ }^{41}$ adotou o critério de menor preço para a escolha das empresas vencedoras. Apesar disso, as inovações contratuais fizeram com que as vantagens comparativas relacionadas à escala e ao poder de mercado das grandes empresas não fossem fatores de maior influência no resultado final do certame.

Na medida em que o modelo de definição de resultados gera incerteza em relação aos meios empregados, as concorrentes acabam sendo estimuladas a apresentarem propostas que empreguem meios eficientes e gerem o menor custo possível (Astone, 2015 , p. 6). Assim, observa-se que os problemas de julgamento pelo menor preço, previamente identificados, nem sempre estarão presentes nas licitações. Isso dependerá, principalmente, do modelo de edital adotado pelo Poder Público.

Ademais, de acordo com o gestor público I e Astone (2015, p. 9), o arranjo contratual im47 "7.1. Para julgamento e classificação das propostas será adotado o critério do menor preço GLOBAL por LOTE conforme Anexo VII deste Edital, observados os requisitos, as especificações técnicas e os parâmetros definidos neste edital e em seus anexos quanto ao objeto" (grifos do Edital). plementado também se mostrou superior ao convencional de definição de meios, pois atraiu um maior número de concorrentes e gerou uma diminuição substancial nos custos da contratação. Essa comparação foi possível porque os dois modelos de contratação foram submetidos a consultas públicas, utilizadas como base para a elaboração da versão final do Edital do Pregão Eletrônico. A superioridade do modelo de definição de resultado resta evidente nas palavras do gestor público I:

Como o projeto começou por um Edital tradicional, feito pela Prodam, um calhamaço monstruoso, cheio de números, especificações e que custava por volta de $\mathrm{R} \$ 160.000 .000,00$ [cento e sessenta milhões de reais], e que terminou como um termo de referência de 14 páginas, que custou $R \$ 28.000 .000,00$ [vinte e oito milhões de reais] e foi entregue em 10 meses, deu para fazer uma comparação de antes e depois muito nítida. $O$ que ela mostrou é que os editais que especificavam de acordo com esse modelo, que eu me referi como mais tradicional, tendiam a ser mais caros, mais burocráticos e as ocorrências de consulta pública que apontavam um direcionamento de licitação eram muito intensas. O segundo modelo foi testado mais ou menos da mesma forma. Ele atraiu muito mais concorrentes, 16 [dezesseis] contra 2 [dois], e chegou a um valor muito mais barato. Inclusive foi analisada a dinâmica de preços da licitação mostrando como a concorrência chegou ao que seria próximo de um preço de equilíbrio. No gráfico, a curva vai descendo muito significativamente e depois ela fica quase constante em diversos lotes de licitação. 
No mais, cabe dizer que, além de apresentar uma perspectiva diversa das licitações de tecnologia, o mesmo gestor público afirmou que o WiFi Livre SP foi chancelado pelos órgãos de controle competentes, o que Ihe conferiu respaldo de segurança jurídica para servir como modelo para outros projetos. Isso porque tanto o Edital do Pregão Eletrônico, quanto os contratos posteriormente celebrados não sofreram impugnações nem alterações quando auditados e apresentados, por exemplo, a empresas privadas, ao Ministério Público Estadual, ao Tribunal de Contas do Município e à Procuradoria-Geral do Município, o que demonstra certa abertura e flexibilidade em relação às inovações.

\subsection{A aplicação do modelo do WiFi Livre SP para a realidade do Mobilab}

Em paralelo à contratação e implementação do Programa WiFi Livre SP, o Mobilab estava passando pelos processos de estruturação e aplicação dos programas descritos na seção 2 do artigo (O arranjo institucional do Mobilab). No entanto, conforme indicou o gestor público II, o Laboratório ainda carecia de uma modelagem jurídica. Isso porque os agentes públicos integrantes pretendiam desenvolver inovações tecnológicas dentro do setor público, ao invés de somente adquirir soluções de TIC prontas e já disponíveis no mercado, o que, na visão do referido entrevistado, seria possível apenas através da contratação de startups.

Havia obstáculos concernentes à construção de um Edital de licitação que possibilitasse isso e, ao mesmo tempo, respeitasse os parâmetros definidos pela Lei Federal $n^{\circ}$ 8.666/1993, bem como restringisse a participação das grandes empresas de tecnologia. Existia o receio de que, caso fosse adotado modelo licitatório tradicional e essa limitação na característica dos concorrentes não fosse feita, as startups não conseguiriam vencer o certame ou nem participariam dele.

Essa preocupação se mostrou verdadeira na medida em que os três agentes privados entrevistados para a presente pesquisa relataram receio de participarem de licitações convencionais por não vislumbrarem chance de sucesso ao concorrerem com empresas maiores. Além disso, eles externaram experiências negativas de participação em processos licitatórios passados no que concerne à falta de transparência na avaliação das propostas dos concorrentes e à dificuldade de receber o pagamento pelo serviço prestado junto ao Poder Público.

Diante disso, atores participantes da construção do modelo utilizado no WiFi Livre SP apresentaram esse arranjo contratual ao Mobilab que, segundo o gestor público II, atendia às necessidades do Laboratório e era coerente do ponto de vista do direito administrativo. Isso foi possível principalmente em razão de relacionamento prévio entre os gestores de ambos os projetos.

Por outro lado, vale dizer que os gestores do WiFi Livre SP realizaram uma tentativa anterior de aplicação desse arranjo no LabProdam ${ }^{42}$. Porém, nas palavras do gestor público I, "por ele [o modelo licitatório baseado na definição dos fins] parecer ser bastante eficiente em evitar que as empresas tradicionais tivessem um grande controle dos resultados licitatórios, foi rejeitado solenemente". Ademais, o LabProdam foi inca${ }^{42}$ LabProdam é uma estrutura da Prodam que busca fomentar o avanço tecnológico, incentivar o surgimento de novas ferramentas e tecnologias e propiciar um ambiente de encontro entre pessoas inovadoras e que tenham interesse em promover avanços tecnológicos e digitais concretos no setor público. Dentre as suas iniciativas estão o contador de ciclistas e o desenvolvimento do portal eletrônico da São Paulo Aberta. Informações disponíveis em http://www.prefeitura. sp.gov.br/cidade/secretarias/controladoria_qeral/noticias/?p=220165. Acesso em 03/08/2017. 
paz de funcionar como deveria, pois estava "muito debaixo da gestão", sendo coordenado e vinculado à Prodam, o que não ocorreu no caso do Mobilab.

Apesar da tentativa anterior frustrada, a maneira enfática pela qual os atores públicos do Mobilab encamparam essa proposta de desenho institucional possibilitou a viabilização do Edital de Projetos nos moldes do WiFi Livre SP. Para escolher os projetos de TIC que seriam licitados, a coordenação do Laboratório, à época a cargo da chefia de gabinete da SPTrans, realizou levantamento prévio junto às diretorias das duas empresas estatais que compõem o Mobilab (CET e SPTrans) sobre os problemas cotidianos nas políticas públicas de mobilidade urbana que poderiam ser solucionados por novas tecnologias. Assim, foi elaborada uma ementa do Edital com 30 (trinta) projetos potenciais. Em seguida, chegou-se ao número final de 14 (quatorze) projetos, que foram transformados em pontos de função ${ }^{43}$ por uma empresa privada contratada pela SMT por meio de ata de registro de preço ${ }^{44}$.

\subsection{A estrutura do Edital de Projetos do Mobilab}

A partir da ideia e dos processos descritos nos dois últimos tópicos, o Edital de Projetos do Mobilab foi publicado em novembro de 2015. Os produtos originários de cada um dos projetos apoiariam ações novas ou já existentes nas políticas de mobilidade urbana, contribuindo para o aprimoramento de processos criativos, inovadores e colaborativos. 43 Ponto de função é um termo criado por Allan Albrecht em 1977 e se
refere a uma unidade de medida de software reconhecida pela ISO/
IEC 209926 para estimar o tamanho de um sistema de informação
baseando-se na funcionalidade percebida do sistema, independen-
temente da tecnologia usada para implementá-lo (Dekkers, 1999).
44 Trata-se da Ata de Registro de Preços TSE $n^{\circ}$ O73/2014, que resul-
tou na celebração do Contrato $n^{\circ}$ O36/2015-SMT, celebrado entre a
SMT e a CTIS Tecnologia S/A, cujo objeto era a prestação de serviços
de informática na área de sustentação de sistemas de informação,
destinado a projetos em desenvolvimento no Mobilab. A íntegra do
contrato está disponível no portal da Transparência da Prefeitura de
São Paulo: http://transparencia.prefeitura.sp.qov.br/contas/Paginas/
Contratos-V2.aspx. Acesso em 25/O7/2017.
Além disso, eles deveriam ter código hospedado em repositório disponível pública e gratuitamente, bem como serem preferencialmente baseados em software livre e licenciados ${ }^{45}$.

Já em relação à escolha da categoria licitatória de concurso, o gestor público I afirmou que isso ocorreu pois ela permite a simplificação, além de conferir maior flexibilidade e objetividade à licitação. A modalidade traz mais interessados dentro do perfil de desenvolvedores autônomos ou startups. ${ }^{46}$ Com isso, os principais critérios para avaliação foram a criatividade, inovação e singularidade das propostas, conforme o potencial de desdobramento do projeto em etapas futuras.

A fim de possibilitar a contratação somente de startups, os itens 3.1. e 3.2. do Edital permitiram a participação de somente pessoas físicas e pessoas jurídicas qualificadas como associações, sociedades civis, microempreendedor individual (MEI), microempresa (ME) ou empresa de pequeno porte (EPP). Apesar disso, segundo o gestor público II, houve a participação de "empresas laranjas" pertencentes a empresas maiores que não atendiam ao requisito de participação. Essas empresas não obtiveram sucesso nos projetos julgados, já que as demais concorrentes apresentaram "projetos mais criativos".

Além disso, essa modalidade licitatória,

\footnotetext{
Por outro lado, cabe ressalvar que o item 1.3.1. do Edital permitia ao autor do produto original utilizá-lo para fins comerciais, desde que respeitadas as regras da licença livre GNU GPL V3.0.

${ }^{46}$ De acordo com o art. 22 da Lei n 8.666/1993, havia outras três modalidades licitatórias como alternativas ao concurso: concorrência, tomada de preços e convite. Em relação à última, vale dizer que o gestor público II afirmou que a adoção dela foi aventada. Porém, ela foi descartada pois não era claro quais seriam as concorrentes para os projetos e a utilização da modalidade convite, segundo o entrevistado, seria arriscada do ponto de vista da participação das grandes empresas de tecnologia da informação, que era algo a ser evitado nessa licitação, conforme dito acima.
} 
prevista no art. 22, inciso IV e $\S 4^{\circ}$ da Lei Federal $n^{\circ}$ 8.666/1993, permitiu que o poder de decisão não ficasse concentrado demasiadamente nos quadros próprios da Prefeitura de São Paulo. Segundo o gestor público I, tais agentes não se sentiam à vontade para tomar decisões sozinhos nos projetos do Mobilab, uma vez que eles trabalhariam perto da fronteira tecnológica na Administração Pública Municipal. Assim, o Mobilab trouxe agente externo para dar suporte à decisão de quais seriam as melhores propostas, visando obter um julgamento muito mais próximo do que seria a melhor técnica dentro da licitação. Nessa toada, vale destacar que as propostas foram avaliadas pela Comissão Julgadora com o auxílio técnico de parecer elaborado pela Fundação Universidade de São Paulo - FUSP, que, nos termos do Contrato $n^{\circ}$ 009/13-SMT.GAB e do item 7.3. do Edital do Concurso Público, era a entidade externa à Prefeitura de São Paulo responsável pelo auxílio técnico na avaliação das propostas.

Observa-se, assim, que o preço do projeto não estava dentro dos critérios utilizados para julgamento das propostas. Isso ocorreu pois, de acordo com o item 4.2.2. do Edital, o valor da premiação paga para cada um dos vencedores seria fixo e não sofreria reajuste em nenhuma hipótese. O valor do prêmio foi fragmentado em diversas parcelas que seriam repassadas às contratadas conforme o cumprimento das etapas do cronograma de cada um dos Termos de Referência ${ }^{47}$. Em outras palavras, a empresa não precisaria entregar previamente o produto final pronto, nem o Poder Público pagaria a

atendimento às etapas dos cronogramas seria verificado pel CTIS Tecnologia S/A, contratada pela Prefeitura de São Paulo. íntegra do valor antes de receber a tecnologia desenvolvida.

Vale observar que a principal semelhança entre as licitações do WiFi Livre SP e do Edital de Projetos do Mobilab é que, em ambos os editais, o Poder Público pautou-se em somente definir as características das soluções tecnológicas que seriam entregues pelos vencedores do certame. Não houve preocupação em definir a maneira pela qual as contratadas prestariam o serviço ou desenvolveriam a tecnologia. Em ambos os casos, procurou-se somente estabelecer os resultados que eram esperados e como eles seriam medidos. ${ }^{48}$

\subsection{A realização do concurso público}

Tendo visto como foram organizadas e estruturadas as principais disposições do edital da licitação estudada, vale observar como elas funcionaram na prática. Com isso, inicialmente, observa-se que as contratadas A, B e C se inscreveram no Edital de Projetos pois entenderam que o arranjo institucional adotado evitaria o surgimento dos problemas que eram vistos como obstáculos para a participação delas em licitações. As contratadas declararam que, ao analisarem as regras definidas pelo Concurso Público, chegaram à conclusão de que não haveria a diminuição das incertezas no que concerne ao resultado da licitação, tendo em vista confiarem que o modelo adotado pela Prefeitura não abriria brechas para a manipulação do julgamento das propostas e na escoIha dos vencedores.

48 O WiFi Livre SP estabeleceu basicamente a velocidade mínima de acesso para cada usuário, os equipamentos que poderiam ser usados para ter acesso à rede (512 kbps efetivos para download e upload) e os locais da cidade que seriam abrangidos pelo serviço gratuito de internet sem fio. Já o Mobilab, se preocupou em estabelecer somente quais eram as funcionalidades obrigatoriamente presentes nas soluções tecnológicas e como sua entrega seria validada pelo Poder Público. Cada um desses requisitos foi classificado de acordo com a sua importância para os atores envolvidos no cotidiano da ação de mobilidade urbana em que a tecnologia seria aplicada. 
A adoção da modalidade concurso público e a opção por critérios de julgamento que priorizassem a inovação e criatividade dos projetos apresentados pelas concorrentes foi, portanto, um dos fatores preponderantes para a participação das empresas. O Edital de Projetos foi encarado não como uma licitação propriamente dita, mas sim como um concurso de inovação tecnológica ${ }^{49}$, em que não haveria influências informais nos re-

\footnotetext{
Destaca-se que, quando questionadas sobre a participação da empresa em licitações anteriores e acerca das diferenças entre esses certames e o Edital de Projetos, as Contratadas B e C externaram, respectivamente as seguintes afirmações: "Na verdade, não foi nem uma licitação. A gente encarou como um concurso"; "Na verdade, não foi uma licitação, mas um concurso público. Do jeito que o Mobilab fez foi chamado de concurso público". A partir disso, talvez seja pos sível inferir que a modalidade adotada licitatória pelo Mobilab evitou que o Edital de Projetos fosse visto através dos pré-conceitos que as empresas tinham em relação a licitações em geral, o que as estimulou a se inscreverem no concurso.
}

sultados. Além disso, nas entrevistas, observou-se que a ausência de grandes empresas no certame e a forma de remuneração diversa da adotada em licitações também foram centrais para a inscrição das startups no Edital de Projetos.

Apesar disso, nem todos os projetos tiveram um número significativo de inscritos, que podem ensejar algumas inferências. Porém, a análise documental e as entrevistas realizadas durante a pesquisa foram insuficientes para esclarecer os motivos para a irregularidade na quantidade de propostas apresentadas em cada um dos projetos, conforme indica o histograma abaixo:

\section{Figura 2 - Quantidade de propostas apresentadas em cada um dos projetos (P) do Edital do Concurso Público nº1/2015-SMT.GAB.}

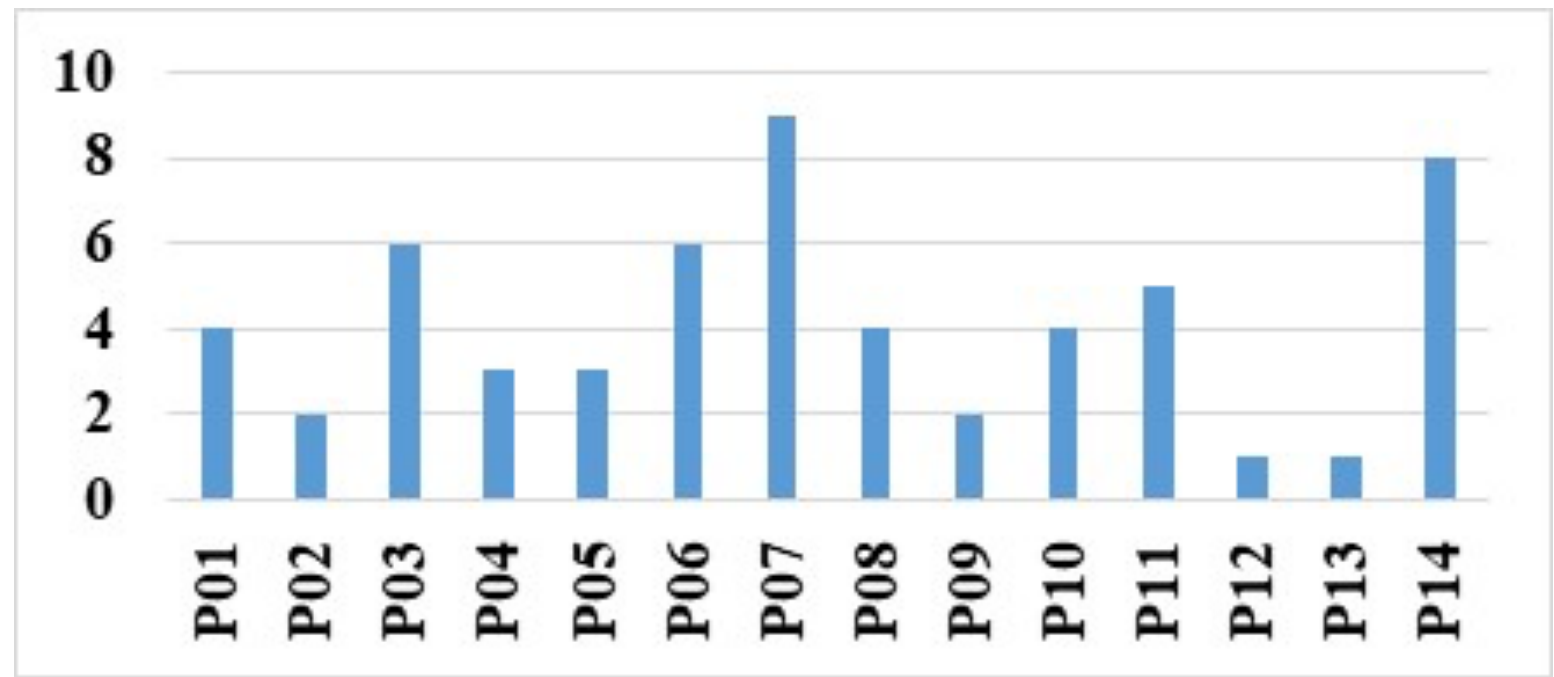

Fonte: Ata de sessão pública de abertura de envelopes contendo propostas para os projetos do Edital de Concurso Público n 001/2015 - SMT, publicada em 12/01/2016, na página 59 do Diário Oficial da Cidade de São Paulo.

Após essa etapa, entre abril e maio de 2016, a Comissão de Licitação do Edital de Projetos do Mobilab divulgou as atas de julgamento de cada um dos projetos. Até maio de 2017, tinham sido publicados no Diário Oficial da Cidade os resultados de seis projetos, o que não se alterou em novembro de 2017: 


\section{Objetivos de cada projeto do Mobilab no Município de São Paulo}

\begin{tabular}{|l|l|}
\hline Projeto & Objetivo \\
\hline P01 & $\begin{array}{l}\text { sistema para a automação de todo o processo de comunicação entre a SPTrans e as empresas } \\
\text { concessionárias ou permissionárias do transporte coletivo sobre pneus }\end{array}$ \\
\hline P02 & $\begin{array}{l}\text { app mobile para auxílio no processo de vistoria e inspeção dos veículos das empresas } \\
\text { contratadas pela concessão e permissão do sistema de transporte sobre pneus }\end{array}$ \\
\hline P08 & $\begin{array}{l}\text { sistema para disponibilizar a extração de relatórios e gráficos das informações geradas a partir } \\
\text { da base de dados das pesquisas nas empresas de transporte de cargas }\end{array}$ \\
\hline P11 & $\begin{array}{l}\text { sistema para realizar a comunicação com os controladores semafóricos, efetuando o envio de } \\
\text { comandos de alteração de planos e recebimento de informações de falhas }\end{array}$ \\
\hline P13* & sistema para análise das informações consolidadas das atividades e ocorrências de trânsito \\
\hline P14 & $\begin{array}{l}\text { sistema que permita que os usuários do transporte público sobre pneus realizem reclamações } \\
\text { utilizando seu smartphone ou tablete, bem como ver o status e o retorno da reclamação }\end{array}$ \\
\hline
\end{tabular}

* Não houve celebração de contrato nesse Projeto. Ele foi declarado prejudicado, pois o único proponente foi desclassificado do Concurso Público.

Fonte: elaboração própria do autor

Em relação aos resultados dos demais projetos, o gestor público II disse que não foram divulgados pois não havia recursos para a contratação de todos os 14 projetos. A Secretaria Municipal de Finanças optou por liberar o montante financeiro suficiente somente para os cinco projetos mencionados acima, em que houve um proponente vencedor. Na visão dos agentes públicos envolvidos na licitação, essa decisão se mostrou acertada, pois acredita-se que a estrutura enxuta do Mobilab seria incapaz de operacionalizar o desenvolvimento de todos os projetos de TIC simultaneamente. O entrevistado disse que ainda há pretensão de reunir a Comissão de Licitação do Edital de Projetos para divulgar os demais resultados, porém, dado o contexto fiscal da Prefeitura, à época, não havia certeza quanto a sua viabilidade do ponto de vista financeiro.

\subsection{A estrutura dos contratos celebrados entre a SMT e as proponentes vencedoras}

Passa-se a apresentar os instrumentos contratuais que regularam a relação entre Prefeitura e proponentes vencedoras, para, pos- teriormente, descrever a sua aplicação no cotidiano do processo de desenvolvimento das tecnologias e, por fim, dizer o estado de cada um dos projetos contratados à época das entrevistas com os atores participantes da licitação (maio e junho de 2017).

Em primeiro lugar, observa-se que, exceção feita ao prazo para execução dos projetos, os cinco contratos são idênticos à minuta de contrato que estava presente no Anexo 20 do Edital do Concurso Público em questão. Nota-se que os contratos abrangiam duas etapas: o desenvolvimento e execução do projeto de TIC e a implantação em produção para fins de operação da tecnologia.

Visando o estabelecimento de competências dos agentes públicos e privados responsáveis pela execução, o item 9.2.3 do Edital previu que a SMT deveria indicar ao menos um gerente de projeto, e um gerente técnico. Já a contratada, designaria, no mínimo, um gerente de projeto, que centralizaria toda a comunicação com a SMT e um líder técnico, que responderia pela gestão técnica da equipe. Conforme itens 9.10. e 9.10.1. 
do Edital, independente da obrigatoriedade das contratadas utilizarem o espaço físico do Mobilab para desenvolvimento das tecnologias, a SMT exigiu das empresas vencedoras a participação presencial em reuniões de frequência semanal, mensal ou ao final de cada fase do cronograma para monitorar e apresentar a visão geral do andamento do projeto.

Em relação aos prazos para execução dos projetos, os agentes privados suscitaram que antes da celebração do contrato, a SMT solicitou diminuição do tempo para desenvolvimento das tecnologias, tendo os contratos vigência até o final de 2016. Segundo a contratada B e o gestor público II, isso ocorreu em razão da vedação presente no art. 42 da Lei de Responsabilidade Fiscal (Lei Complementar $n^{\circ} 101 / 2000$ ), que impossibilitou a previsão de despesas financeiras dessa licitação para 2017, visto que o então prefeito Fernando Haddad estava em seu último ano de mandato. ${ }^{50}$

\subsection{A execução dos contratos}

Quanto ao seu funcionamento, os cinco contratos celebrados não encontraram obstáculos em órgãos de controle da Administração Pública. Segundo o gestor público II, - Tribunal de Contas do Município de São Paulo apenas enviou à SMT pedido de esclarecimentos sobre o Edital de Projetos em razão de possível sobreposição de objeto, o que não resultou em abertura de processo administrativo ${ }^{51}$.

50 Com isso, exceção feita ao P08, cuja previsão inicial para execução do projeto estava dentro das limitações previstas na Lei de Responsabilidade Fiscal, os prazos foram diminuídos. Nos P01 e P02, os prazos passaram de 193 dias úteis para 146 e 131 dias úteis, respectivamente. Já os $\mathrm{P} 11$ e P14 tiveram os prazos reduzidos em quase $50 \%$, de 246 dias úteis para 130 e 128 dias úteis, respectivamente. Informações presentes nos Termos de Referência dos Projetos e nos Contratos celebrados entre a SMT e os vencedores dos projetos.

Em 07/08/2017, foi realizada busca de processos administrativos relacionados ao Edital de Projetos no portal eletrônico do Tribunal de Contas do Município (https://portal.tcm.sp.gov.br/). Nesse sentido, no espaço de "busca avançada" da seção de "Consulta Processual", a busca foi filtrada por processos relacionados à SMT nos anos de 2015,2016 e 2017. Com isso, foram encontrados 78 resultados e não nenhum dos processos tratava do objeto do presente trabalho.
Até junho de 2017, dentre os cinco projetos de TIC contratados pela SMT, quatro deles (P01, P02, P08 e P11) foram desenvolvidos e entregues, enquanto o P14 não estava finalizado. Isso porque a empresa contratada não conseguiu entregar o produto dentro do cronograma, apesar de a Prefeitura ter conferido todas as condições para que isso tivesse ocorrido, de acordo com o gestor público II. Assim, o Poder Público glosou o contrato celebrado e, com o recurso reavido, pretende terminar o projeto usando a Ata de Registro de Preço TSE nº 073/2014.

Apesar do relativo insucesso de um dos projetos, as empresas entrevistadas citaram alguns fatores positivos imprescindíveis para o sucesso da execução dos demais. Segundo a contratada A, um dos principais fatores foi a flexibilidade do Termo de Referência (TR), em que as especificações tinham "buracos" que possibilitavam alternativas. Essa característica, que já estava presente nos projetos de tecnologia da iniciativa privada, garantiu o andamento do projeto, uma vez que o levantamento detalhado de todo o projeto é algo muito difícil de ser realizado na etapa de contratação e acaba por tornar o TR tão rígido a ponto de inviabilizar a entrega do produto final. Por outro lado, as contratadas A e B afirmaram que o Edital poderia ter maior aprofundamento no TR, o que evitaria demasiados "buracos" e pouparia tempo gasto para adaptações no meio do caminho.

Além disso, os agentes privados entrevistados citaram positivamente a participação da CTIS Tecnologia S/A, que facilitou o gerenciamento do tempo do projeto. Essa empresa ficou responsável por realizar a governança de Tecnologia da Informação e Comunicação nos projetos do Mobilab, e participava de reuniões com as empresas 
contratadas. Junto a isso, as Contratadas A e B citaram como fator positivo o engajamento, a disposição e o conhecimento dos servidores da Prefeitura para que o desenvolvimento das tecnologias ocorresse dentro do cronograma acordado.

Porém, a Contratada C externou descontentamento com a falta de engajamento de alguns agentes públicos, que, segundo ela, priorizaram outros projetos em detrimento do que estava envolvida, o que gerou atrasos no cronograma. Na visão dessa entrevistada, esse problema ocorreu em razão: $(i)$ da diminuição do prazo para a entrega do produto final; e (ii) do fato de os agentes públicos da Prefeitura estarem acostumados a trabalhar com grandes empresas de tecnologia que, em geral, seriam contratadas por hora e não por projeto, como foi o caso do Edital de Projetos.

Ademais, a contratada B citou que a definição prévia das competências de todos os agentes públicos e privados que participariam da execução do projeto foi um elemento chave para o sucesso do desenvolvimento da tecnologia. Essa definição clara dos papeis permitiu que a empresa e o Poder Público tivessem relação transparente e célere no que concerne ao seguimento do cronograma, à validação de cada etapa concluída e ao envio de feedbacks para eventuais ajustes.

Por outro lado, apesar de todos os pontos positivos destacados acimas, observa-se que somente a tecnologia resultante do P08 estava em operação em junho de 2017 - os outros três projetos desenvolvidos estavam aguardando para entrar em produção. Segundo o gestor público II, isso se deve, principalmente, à oposição de agentes públicos ao modelo de contratação de tecno- logia adotado. Ele afirmou que os servidores dos setores de informática e tecnologia de informação da SMT, SPTrans e CET preferem trabalhar com contratos de longo prazo, firmados com empresas maiores, e consideram que as startups contratadas não são do mercado de tecnologia no setor público.

Como evidência, o entrevistado citou dois fatos: (i) a quantidade de tempo demandada para operacionalizar um projeto foi a mesma para desenvolver quatro projetos inteiros; e (ii) o P11 é eficiente em diminuir substancialmente custos de um controle semafórico automatizado. Por isso, a oposição a ele dentro da Prefeitura de São Paulo é "enorme", havendo desconfiança de que isso se deva a influência de grandes empresas de tecnologia normalmente contratadas pelo Poder Público.

Apesar das entrevistas realizadas não terem abordado essa questão, através das regras presentes no Edital e nos contratos celebrados, é possível dizer que a oposição de setores internos da Prefeitura para a implementação das soluções tecnológicas contratadas não foi identificada no momento de concepção do Concurso Público. Isso porque previa-se que, uma vez terminado desenvolvimento da tecnologia, passar-se-ia imediatamente à fase de operação assistida, em que a empresa contratada acompanharia a implantação e a produção do produto final, o que ainda não ocorreu em três projetos. Diante desse entrave, o gestor público II afirmou que ainda não é possível avaliar se as tecnologias desenvolvidas atenderam às necessidades da Prefeitura, apesar de considerar a forma de contratação uma experiência positiva, que poderia ser classificada como "disruptiva".

No entanto, esse não é o único gargalo 
identificado nas entrevistas. A contratada A afirmou que encontrou problemas nos processos burocráticos internos da Prefeitura, que não estavam na mesma velocidade do projeto de tecnologia contratado. Houve dificuldades e atrasos em receber o pagamento da premiação após a finalização de determinadas etapas do cronograma de execução, o que acabou exigindo da empresa um fluxo de caixa para o cumprimento das etapas dentro do prazo.

Por fim, vale dizer que a despeito dos obstáculos e gargalos citados acima, os três agentes privados entrevistados avaliaram como positiva a experiência de participarem do Edital de Projetos do Mobilab e desenvolverem tecnologia em conjunto com a Prefeitura de São Paulo. As Contratadas A e B afirmaram que entraram na licitação sem muitas perspectivas, mas se surpreenderam positivamente e pretendem participar de novos certames que adotem o mesmo arranjo institucional. Já a Contratada C considera que o modelo adotado no Concurso Público é um caso a ser seguido por outros órgãos públicos nas contratações públicas de tecnologia, apesar de ter dito que não pretende participar de novas licitações por estar alterando seu modelo de negócios.

\section{CONCLUSÃO: O CASO DO MOBILAB SOB A PERSPECTIVA DO DIREITO NAS POLÍTICAS PÚBLICAS}

O estudo de caso sobre o Edital de Projetos do Mobilab mostrou que, a despeito do caminho de dependência estabelecido pela Lei n 8.666/1993, os administradores públicos, em geral, possuem certa margem de discricionariedade para a implementação de inovações que visam mitigar ou contornar os gargalos levantados no capítulo introdutório. No entanto, faz-se necessário ressaltar que a pesquisa apresentou quatro principais peculiaridades que possibilitaram o efetivo aproveitamento dessa margem para a criação de arranjos institucionais nas licitações de tecnologia: (i) o respaldo que determinados quadros da Prefeitura receberam para a implementação de um novo modelo licitatório; (ii) a estrutura jurídica dos órgãos públicos municipais que aplicaram o modelo; (iii) a chancela recebida pelos órgãos de controle; e (iv) a existência de uma agenda de políticas públicas voltada à inovação tecnológica através da interação entre setores público e privado.

Ademais, a pesquisa permitiu captar uma dinâmica de experimentalismo e aprendizado institucional no manejo das ferramentas jurídicas. Isso pode ser visto como uma tentativa de valoração dos processos criativos de construção de arranjos inovadores, de forma a evitar a utilização de modelos pré-concebidos. Com isso, procurou-se enfatizar a aquisição de conhecimento enquanto processo coletivo e indeterminado, capaz de demonstrar resultados positivos quando reconhece sua própria indeterminação (Sabel; Reddy, 2007, p. 12).

Nesse sentido, nota-se que o Edital de Projetos pode servir como um exemplo de que é possível contornar alguns os problemas encontrados comumente em contratações de tecnologia. Apesar de a Lei n 8.666/1993 induzir à implementação de um modelo licitatório enrijecido que preze pelo detaIhamento dos meios de implementação do objeto contratual, a aplicação do ferramental teórico e jurídico relacionado ao campo das políticas públicas permitiu o desenho de um modelo que respeitasse as normas vigentes sobre o tema e, ao mesmo tempo, fosse diverso do que é cotidianamente feito na Administração Pública. 
Esse fato evidencia que, além dos problemas de construção do arcabouço jurídico-institucional, deve-se atentar também à maneira como os juristas, na posição de formuladores de políticas públicas, manejam as ferramentas à sua disposição, fornecidas pela doutrina e pela legislação em vigor. Isso porque o caso do Mobilab mostrou a centralidade da existência de iniciativa dos atores envolvidos para a construção de arranjos inovadores dotados de flexibilidade e revisibilidade. Entretanto, ressalta-se que não se trata somente de disposição dos agentes públicos, pois há uma série de outros fatores que influenciam o sucesso ou insucesso na implementação da política pública.

Além disso, as entrevistas com os atores envolvidos no Edital de Projetos identificaram a aplicação do "direito administrativo das políticas públicas" (Annenberg, 2014 , p. 140). Em outras palavras, nota-se que a construção do Concurso Público $n^{\circ}$ 001/2015-SMT.GAB ocorreu, na medida do permitido pela legislação licitatória, com base na realização na ideia de elaborar um edital flexível e adaptável às possíveis dificuldades que poderiam surgir ao longo do desenvolvimento das tecnologias. Junto ao método de julgamento das propostas, isso acabou por incentivar as concorrentes a aplicarem criatividade e experimentação para desenvolverem as propostas apresentadas à Prefeitura.

Junto a isso, observa-se que houve a descentralização do poder de decisão tanto no momento de julgamento das propostas quanto na fase de execução contratual, visto que, dependendo do projeto, a interação do particular contratado ocorreria com uma das instituições integrantes do Mobilab, apesar dos contratos terem sido celebrados com a SMT. Dessa forma, es- sas categorias jurídicas vão de encontro às do "direito administrativo tradicional" (Annenberg, 2014, p. 140), caracterizadas como rígidas e fixas, com mecanismos de comando e controle, imposição de regras de proibição e coerção, bem como a relação hierárquica e hermética entre Administração Pública e particular.

Ao abrir mão de um modelo reconhecidamente problemático e buscar a formulação de um novo arranjo institucional, o concurso público do Mobilab deixa evidente dois principais pontos sobre o tema das contratações públicas de tecnologia. Em primeiro lugar, tratam-se de licitações de natureza peculiar, não sendo possível tratá-las como compras públicas triviais e comuns. Por isso, deve-se priorizar modelos próprios que não estejam embasados em arranjos licitatórios aplicados para contratações de outras naturezas, como obras de infraestrutura civil.

O segundo ponto é o reconhecimento, pelo Poder Público, da assimetria de informação em relação à sociedade e ao mercado quando se trata de inovação tecnológica. Partindo dessa premissa, o modelo de contratação pública de tecnologia baseado na definição dos resultados esperados devolve a esses segmentos a capacidade de proporem uma solução tecnológica adequada. Esse fato pode representar um novo caminho a ser seguido em licitações desse tipo 52 , já que foi eficaz em contornar alguns dos problemas identificados no presente trabalho, conforme se observa pela tabela abaixo:

52 Vale ressaltar que a comparação entre o modelo licitatório de definição de resultados e o que busca detalhar exaustivamente os meios de desenvolvimento e implementação da tecnologia é objeto de debates estrangeiros sobre as contrações públicas de tecnologia. Para maiores detalhes, ver (MCCONNELL, 1996, p. 382)

${ }^{53} \mathrm{~A}$ título de exemplo de replicação desse modelo de contratação, pode-se citar o Concurso INOVApps (Edital n 54/2015/SEI-MC) promovido pelo então Ministério das Comunicações, cujo objetivo é apoiar o desenvolvimento de aplicativos de interesse público para dispositivos móveis e TVs digitais conectadas. Maiores informações podem ser obtidas em: http://www2.mcti.gov.br/index.php/conteudos-digitais-criativos/inovapps/concurso-inovapps. Acesso em 10/08/2017. 


\section{Medidas do Mobilab para contornar gargalos nas contratações públicas de tecnologia}

\begin{tabular}{|l|l|}
\hline Entraves nas licitações de tecnologia & Soluções adotadas pelo Edital de Projetos \\
\hline $\begin{array}{l}\text { Foco excessivo no procedimento } \\
\text { licitatório e pouco nos resultados do } \\
\text { contrato originário desse processo. }\end{array}$ & $\begin{array}{l}\text { Aplicação de um modelo contratual de definição dos resultados } \\
\text { esperados, em detrimento do modelo convencional de } \\
\text { especificaçães de meios. }\end{array}$ \\
\hline $\begin{array}{l}\text { Descrição minuciosa do equipamento } \\
\text { ou serviço licitado no edital do certame, } \\
\text { dificultando o enquadramento de } \\
\text { soluções inovadoras. }\end{array}$ & $\begin{array}{l}\text { Formulação de Termos de Referência que apresentassem mais } \\
\text { de uma saída para uma mesma questão. } \\
\text { Adoção da modalidade de concurso público, cujos principais } \\
\text { critérios de julgamento eram baseados na inovação e } \\
\text { criatividade das propostas apresentadas pelas concorrentes. }\end{array}$ \\
\hline $\begin{array}{l}\text { Formalismo e inflexibilidade dos } \\
\text { órgãos de controle na interpretação da } \\
\text { legislação vigente. }\end{array}$ & $\begin{array}{l}\text { O aprendizado institucional por meio da adoção do modelo de } \\
\text { contratual que já havia sido implementado no programa do WiFi } \\
\text { Livre SP e que fora chancelado pelos órgãos de controle. }\end{array}$ \\
\hline $\begin{array}{l}\text { Falta de capacidade institucional para } \\
\text { identificar o tipo de demanda por } \\
\text { tecnologia dentro do setor público e } \\
\text { desenhar editais que possibilitem a } \\
\text { contratação de produtos que a supram. }\end{array}$ & $\begin{array}{l}\text { Contratação de empresa de tecnologia para a construção dos } \\
\text { Termos de Referência, que foram elaborados com base no } \\
\text { modelo contratual de definição dos resultados e a partir das } \\
\text { demandas por tecnologia identificadas nas diretorias da SPTrans } \\
\text { e da CET. }\end{array}$ \\
\hline $\begin{array}{l}\text { Influência das grandes empresas de } \\
\text { tecnologia nos processos de desenhos } \\
\text { dos editais e dos contratos públicos. }\end{array}$ & $\begin{array}{l}\text { Aplicação de um modelo contratual de definição dos resultados } \\
\text { esperados, em detrimento do modelo convencional de } \\
\text { especificações de meios. } \\
\text { Restrição de participação para somente pessoas físicas ou } \\
\text { pessoas jurídicas enquadradas como associação, sociedade civil, } \\
\text { MEl, ME ou EPP. }\end{array}$ \\
\hline
\end{tabular}

Por outro lado, isso não quer dizer que o Edital de Projetos do Mobilab representa um modelo pronto e acabado, capaz de solucionar todos os gargalos jurídicos presentes nas licitações de tecnologia. Ainda permanecem, desafios práticos nas contratações públicas de tecnologia. Além disso, as inovações institucionais identificadas no Mobilab não diminuem ou relativizam a necessidade de repensar o modelo de licitações estabelecido pela Lei n 8.666/1993, que pode ser redesenhado através de uma reforma legislativa ou pela edição de lei específica disciplinando as licitações de tecnologia.

Nesse sentido, o Concurso Público estudado apresentou limitações no que concerne à quantidade de atores participantes da elaboração do Edital e à quantidade de tempo demandada para operacionalizar as tecnologias desenvolvidas. Nesse sentido, os gestores públicos entrevistados indicaram dois principais pontos que poderiam ser aprimorados para a continuidade da política pública.

Em primeiro lugar, considerou-se que os contratos celebrados com as proponentes vencedoras poderiam prever dispositivos que exercessem alguma coerção sobre os setores de TI da Prefeitura de São Paulo, para que as tecnologias desenvolvidas não demorassem tanto tempo serem produzidas e operacionalizadas na prática. Nesse sentido, dois caminhos possíveis seriam estender os prazos de vigência dos contratos e estabelecer que a contratante perderia a garantia da tecnologia caso esta não fosse implementada até um determinado período após a entrega do produto final pela contratada. 
Já o segundo ponto de aprimoramento indicado pelos entrevistados seria o envolvimento de um número maior de atores públicos e privados na construção do edital de licitação e nas especificações das tecnologias pretendidas. Para isso, uma saída seria a aplicação de modelo licitatório semelhante ao do Concurso Público do Mobilab para a contratação da empresa responsável pela construção dos TRs e da governança de TI dos projetos contratados pela SMT. Assim, seria possível realizar consulta pública sobre formas de especificações das soluções a serem desenvolvidas.

Outros dois principais desafios a serem encarados por gestores públicos seriam a utilização do potencial dos Dados Abertos Governamentais para a construção de alternativas institucionais às licitações e a construção de um modelo contratual que permitisse a replicação do arranjo institucional adotado pelo Edital de Projetos em outros municípios ou entes federativos e em licitações de maior porte. Nesse sentido, um primeiro cuidado seria não considerar o modelo do Mobilab como uma política pronta passível de ser aplicada em qualquer contexto político, social, econômico e jurídico.

Por fim, nota-se que as contratações públicas de tecnologia representam uma agenda de pesquisa no campo do direito nas políticas públicas que ainda está por ser explorada. Nesse sentido, três possíveis próximos caminhos a serem seguidos por futuros trabalhos acadêmicos na área seriam: (i) compreender a lógica de funcionamento e os atores envolvidos no mercado de empresas de tecnologia contratadas pelo Poder Público; (ii) identificar estruturas e processos jurídicos e administrativos que permitem e/ ou facilitam a captura do Poder Público por empresas durante a fase de elaboração dos editais de licitações de tecnologia; e (iii) levantar a maneira como as contratações de tecnologia são estruturadas em outras localidades do país e em que medida elas buscam implementar inovações institucionais ou somente replicam modelos convencionais e defasados.

\section{REFERÊNCIAS}

Annenberg, F. X. (2014) Direito e Políticas Públicas: Uma Análise Crítica de Abordagens Tradicionais do Direito Administrativo a partir de um estudo do Programa Bolsa Família. Dissertação (Mestrado) - Faculdade de Direito, Universidade de São Paulo. Disponível em: <http://www.teses.usp.br/teses/disponiveis/2/2133/ tde-11022015-114706/pt-br.php>. Acesso em 27/04/2017. Astone, D. (2015) "Evidences about the role of uncertainty and result definition in public contracting". 1Oth Research Workshop on Institutions and Organizations - RWIO, Rio de Janeiro. Center For Organization Studies - CORS. Disponível em: <http://cors.usp. br/rwio/10rwio/34.pdf.>. Acesso em 17/05/2017.

Coutinho, D. R. (2013). O Direito nas Políticas Públicas. In: E. Marques, C. A. P. Faria (Org.), A Política Pública como Campo Multidisciplinar (pp. 181-200). São Paulo e Rio de Janeiro: Fiocruz e Unesp.

Coutinho, D. R.; Mouallem, P. S. (2016). "O Direito Contra a Inovação?" A Persistência dos Gargalos à Inovação no Brasil. In: H. M.M. Lastres, J. E. Cassiolato, G. Laplane, F. Sarti. (Org.). O Futuro do Desenvolvimento: ensaios em homenagem a Luciano Coutinho (pp. 181214). Campinas: Unicamp.

Dallari Bucci, M. P. (2013). Fundamentos para uma Teoria Jurídica das Políticas Públicas. São Paulo: Saraiva. Dekkers, C. A. (1999) Pontos de função e medidas: O que é um ponto de função. Tradução de Mauricio Aguiar. Disponível em <http://www.bfpug.com.br/ Artigos/Dekkers-PontosDeFuncaoEMedidas.htm>. Acesso em 03/08/2017.

Gomide, A. Á.; Galindo, E. P. (2013) “A mobilidade urbana": uma agenda inconclusa ou o retorno daquilo que não foi. Estud. av. [online]. 27(79), 27-39. Disponível em: http://www.scielo.br/scielo.php?script=sci_arttext\&pi$d=S 0103-40142013000300003$. Acesso em 31/07/2016. Gomide, A. Á.; Pires, R. R. C. (2014) "Capacidades Es- 
tatais e Democracia": A abordagem dos arranjos institucionais para análise de políticas públicas. In: A. Á. Gomide, R. R. C. Pires (Org.) Capacidades Estatais e Democracia: Arranjos Institucionais de Políticas Públicas. (pp. 15-28). Brasília: Ipea.

Marques, E. (2013). "As Políticas Públicas na Ciência Política". In: E. Marques, C. A. P. Faria. A Política Pública como Campo Multidisciplinar (pp. 23-46). São Paulo e Rio de Janeiro: Fiocruz e Unesp, 2013.

May, T. (2004). Pesquisa Social: questões, métodos e processos. Porto Alegre: Artmed. Tradução Carlos Alberto Silveira Netto Soares.

Mcconnell, M. E. (1996) "The Process of Procuring Information Technology". Public Contract Law Journal, 25(2), 379-392.

Palma, J. B. (2015). "Contratações Públicas Sustentáveis". In C. A. Sundfeld, G. J. Jurksaitis. Contratos Públicos e Direito Administrativo (pp. 80-113). São Paulo: Malheiros, 2015.

Prado, M. M. Institutional Bypass: An Alternative for Development Reform, SSRN Scholarly Paper, Rochester, NY: Social Science Research Network. Disponível em: https://papers.ssrn.com/sol3/papers.cfm?abstract_id=1815442. Acesso em 19/07/2017.

Rosilho, A. (2013). Licitação no Brasil. São Paulo: MaIheiros.

Sabel, C. F.; Reddy, S. (2007). "Learning to learn": Undoing the Gordian Knot of Development Today. In Challenge, 50(5).

Salama, B.; Barrionuevo, A. (coord.) (2016). Processo de Nomeação de Dirigentes de Agências Reguladoras: uma análise descritiva. São Paulo: FGV-SP. Disponível em: http://direitosp.fgv.br/sites/direitosp.fgv.br/files/ arquivos/GRP_arquivos/grp_-_relatorio_de_pesquisa_-_nomeacao_de_dirigentes_nas_agencias_reguladoras_sponsor.pdf

Souza, C. (2007). "Estado da Arte da Pesquisa em Políticas Públicas". In G. Hochman, M. Arretche, E. Marques. Políticas Públicas no Brasil (pp. 65-86). Rio de Janeiro: Fiocruz.

Tribunal de Contas da União. (2012). Guia de boas práticas em contratação de soluções de tecnologia da informação: riscos e controles para o planejamento da contratação. Brasília: TCU.

Vaz, J. C.; Ribeiro, M. M.; Ricardo, M.. (2010). “Dados governamentais abertos e seus impactos sobre os conceitos e práticas de transparência no Brasil". Cadernos ppg-au/ufba, 9(1).

Vojvodic, A. M.; Astone, D.; Vilella, M. (2015). Compras de tecnologia e inovação pelos órgãos públicos de educação: análise de entraves e propostas para aquisição. São Paulo: Internetlab.

Yin, R. (2015). Estudo de caso: planejamento e método. Porto Alegre: Bookman.

Data de submissão: 22/03/2018

Data de aceite: 22/01/2020 